\title{
Algoriphagus terrigena sp. nov., isolated from soil
}

Correspondence

Jung-Hoon Yoon

jhyoon@kribb.re.kr

Tae-Kwang Oh

otk@kribb.re.kr
Jung-Hoon Yoon, Mi-Hwa Lee, So-Jung Kang and Tae-Kwang Oh

Korea Research Institute of Bioscience and Biotechnology (KRIBB), PO Box 115, Yusong, Taejon, Korea

A Gram-negative, non-motile, non-spore-forming bacterial strain, DS- $44^{\top}$, was isolated from soil from Dokdo in Korea, and its taxonomic position was investigated by using a polyphasic approach. It grew optimally at $25^{\circ} \mathrm{C}$ and in the presence of $2 \%(\mathrm{w} / \mathrm{v}) \mathrm{NaCl}$. Strain DS-44 $4^{\top}$ contained MK-7 as the predominant menaquinone and iso- $\mathrm{C}_{15: 0}$ and $\mathrm{C}_{16: 1} \omega 7 \mathrm{c}$ and/or iso- $\mathrm{C}_{15: 0} 2-\mathrm{OH}$ as the major fatty acids. The DNA G $+\mathrm{C}$ content was $49 \cdot 0 \mathrm{~mol} \%$. Phylogenetic analyses based on 16S rRNA gene sequences revealed that strain $\mathrm{DS}-44^{\top}$ belongs to the genus Algoriphagus of the phylum Bacteroidetes. Similarity values between the $16 \mathrm{~S}$ rRNA gene sequences of strain DS- $44^{\top}$ and those of the type strains of recognized Algoriphagus species were in the range 93.8-95.7\%, making it possible to categorize strain $D S-44^{\top}$ as a species that is separate from previously described Algoriphagus species. On the basis of its phenotypic properties and phylogenetic distinctiveness, strain DS- $44^{\top}\left(=\right.$ KCTC $12545^{\top}=$ CIP $\left.108837^{\top}\right)$ was classified in the genus Algoriphagus as the type strain of a novel species, for which the name Algoriphagus terrigena sp. nov. is proposed.
The genus Algoriphagus was first described by Bowman et al. (2003). At the time of writing, the genus consists of eight species with validly published names: Algoriphagus ratkowskyi (the type species; Bowman et al., 2003), A. aquimarinus, A. chordae and A. winogradskyi (Nedashkovskaya et al., 2004), A. halophilus (Yi \& Chun, 2004; Nedashkovskaya et al., 2004), A. antarcticus (Van Trappen et al., 2004), A. yeomjeoni (Yoon et al., 2005a) and A. locisalis (Yoon et al., 2005b). Algoriphagus species have been isolated from marine environments, Antarctic lakes and salterns (Bowman et al., 2003; Nedashkovskaya et al., 2004; Van Trappen et al., 2004; Yoon et al., 2005a, b). In this study, we report on the taxonomic characterization of an Algoriphagus-like bacterial strain, DS- $44^{\mathrm{T}}$, which was isolated from soil from Dokdo in Korea.

Strain DS $-44^{\mathrm{T}}$ was isolated by using the standard dilution plating technique on $10 \times$ diluted nutrient agar (Difco) with distilled water at $25^{\circ} \mathrm{C}$. The morphological, physiological and biochemical characteristics of strain DS- $44^{\mathrm{T}}$ were investigated using routine cultivation on marine agar 2216 (MA; Difco) at $25^{\circ} \mathrm{C}$. The cell morphology was examined by using light microscopy (E600; Nikon) and transmission electron microscopy. The presence of flagella was determined using a transmission electron microscope with cells from exponentially growing cultures. Gliding motility was investigated as

Published online ahead of print on 16 December 2005 as DOI 10.1099/ijs.0.64092-0.

The GenBank/EMBL/DDBJ accession number for the 16S rRNA gene sequence of strain DS- $44^{\top}$ is DQ178979.

Details of the fatty acid compositions of Algoriphagus species are available in a supplementary table in IJSEM Online. described by Bowman (2000). The Gram reaction was determined by using the bioMérieux Gram stain kit according to the manufacturer's instructions. The $\mathrm{pH}$ range for growth was determined in marine broth 2216 (MB; Difco) adjusted to various $\mathrm{pH}$ values $(\mathrm{pH} 4 \cdot 5-10 \cdot 5$ at increments of $0.5 \mathrm{pH}$ units). Before sterilization, the $\mathrm{pH}$ was adjusted to various levels by the addition of $\mathrm{HCl}$ or $\mathrm{Na}_{2} \mathrm{CO}_{3}$. Growth in the absence of $\mathrm{NaCl}$ was investigated in trypticase soy broth prepared according to the formula of the Difco medium except that no $\mathrm{NaCl}$ was used. Growth at various $\mathrm{NaCl}$ concentrations $[0.5 \%(\mathrm{w} / \mathrm{v})$ and $1 \cdot 0-10 \cdot 0 \%(\mathrm{w} / \mathrm{v})$ at increments of $1.0 \%$ ] was investigated in $\mathrm{MB}$ or trypticase soy broth (Difco). Growth at various temperatures $\left(4-40{ }^{\circ} \mathrm{C}\right)$ was measured on MA. Growth under anaerobic conditions was determined after incubation in an anaerobic chamber on MA and on MA supplemented with nitrate, both of which had been prepared anaerobically under nitrogen. Catalase and oxidase activities and the hydrolysis of casein, gelatin, hypoxanthine, starch, Tweens 20, 40, 60 and 80, L-tyrosine, urea and xanthine were determined as described by Cowan \& Steel (1965). The hydrolysis of aesculin and the reduction of nitrate were studied as described previously (Lanyi, 1987). $\mathrm{H}_{2} \mathrm{~S}$ production was tested as described previously (Bruns et al., 2001). The presence of flexirubin-type pigments was investigated as described by Reichenbach (1992). Acid production from carbohydrates was determined as described by Leifson (1963). Utilization of substrates as sole carbon and energy sources was tested as described by Baumann \& Baumann (1981), using supplementation with $2 \%(\mathrm{v} / \mathrm{v})$ Hutner's mineral base (CohenBazire et al., 1957) and $1 \%(\mathrm{v} / \mathrm{v})$ vitamin solution (Staley, 1968). Susceptibility to antibiotics was tested on MA plates 
using antibiotic discs containing the following concentrations: polymyxin B, $100 \mathrm{U}$; streptomycin, $50 \mu \mathrm{g}$; penicillin $\mathrm{G}$, $20 \mathrm{U}$; chloramphenicol, $100 \mu \mathrm{g}$; ampicillin, $10 \mu \mathrm{g}$; cephalothin, $30 \mu \mathrm{g}$; gentamicin, $30 \mu \mathrm{g}$; novobiocin, $5 \mu \mathrm{g}$; tetracycline, $30 \mu \mathrm{g}$; kanamycin, $30 \mu \mathrm{g}$; lincomycin, $15 \mu \mathrm{g}$; oleandomycin, $15 \mu \mathrm{g}$; neomycin, $30 \mu \mathrm{g}$; carbenicillin, $100 \mu \mathrm{g}$. Other physiological and biochemical tests were performed with the API 20E and API ZYM systems (bioMérieux).

Cell biomass of strain DS- $44^{\mathrm{T}}$ for DNA extraction and for isoprenoid quinone analysis was obtained by cultivation for
3 days in $\mathrm{MB}$ at $25^{\circ} \mathrm{C}$. Chromosomal DNA was isolated and purified according to a method described previously (Yoon et al., 1996), except that RNase T1 was used in combination with RNase A to minimize contamination with RNA. The $16 \mathrm{~S}$ rRNA gene was amplified by using a PCR with two universal primers, as described previously (Yoon et al., 1998). Sequencing of the amplified 16S rRNA gene and phylogenetic analyses were performed as described by Yoon et al. (2003). Isoprenoid quinones were extracted according to the method of Komagata \& Suzuki (1987) and analysed using reversed-phase HPLC with a YMC ODS-A

Table 1. Differential phenotypic characteristics of Algoriphagus species

Species: 1, A. terrigena sp. nov.; 2, A. ratkowskyi; 3, A. aquimarinus; 4, A. chordae; 5, A. winogradskyi; 6, A. halophilus; 7, A. antarcticus; 8, A. yeomjeoni; 9, A. locisalis. Data are from Bowman et al. (2003), Yi \& Chun (2004), Nedashkovskaya et al. (2004), Van Trappen et al. (2004) and Yoon et al. (2005a, b). +, Positive; -, negative; V, variable reaction; ND, not determined. Data in parentheses are for the type strain. All species are Gram-negative and rod-shaped and positive for catalase and oxidase. All species are negative for gliding motility, flexirubin-type pigment production, $\mathrm{H}_{2} \mathrm{~S}$ and indole production, utilization of citrate and susceptibility to ampicillin, benzylpenicillin, gentamicin, kanamycin, neomycin, polymyxin B and streptomycin.

\begin{tabular}{|c|c|c|c|c|c|c|c|c|c|}
\hline Characteristic & 1 & 2 & 3 & 4 & 5 & 6 & 7 & 8 & 9 \\
\hline Nitrate reduction & + & - & - & - & + & - & - & - & - \\
\hline $\mathrm{NaCl}$ requirement for growth & + & + & - & + & - & - & ND & + & + \\
\hline Optimal temperature for growth $\left({ }^{\circ} \mathrm{C}\right)$ & 25 & $16-19$ & $23-25$ & $23-25$ & $25-28$ & 35 & 20 & $25-30$ & 30 \\
\hline \multicolumn{10}{|l|}{ Growth at/in: } \\
\hline $10 \% \mathrm{NaCl}$ & - & - & + & + & - & - & - & - & - \\
\hline $37^{\circ} \mathrm{C}$ & - & - & - & - & + & + & - & - & - \\
\hline \multicolumn{10}{|l|}{ Hydrolysis of: } \\
\hline Agar & - & - & + & + & + & - & - & - & - \\
\hline Casein & + & $\mathrm{V}$ & + & - & - & - & - & + & - \\
\hline Gelatin & - & - & + & - & + & + & - & $\mathrm{v}(+)$ & - \\
\hline Starch & - & $\mathrm{V}$ & - & - & + & + & - & - & - \\
\hline Tween 80 & + & - & + & - & - & + & ND & + & + \\
\hline \multicolumn{10}{|l|}{ Acid production from: } \\
\hline L-Arabinose & + & + & - & - & - & - & - & - & + \\
\hline D-Cellobiose & + & + & + & + & + & - & ND & + & + \\
\hline D-Galactose & + & + & - & + & + & - & $\mathrm{ND}$ & + & + \\
\hline D-Glucose & + & + & + & + & + & + & - & + & + \\
\hline Lactose & + & - & + & + & + & - & $\mathrm{ND}$ & + & + \\
\hline Maltose & + & + & - & + & + & + & $\mathrm{ND}$ & + & + \\
\hline D-Melibiose & + & + & + & + & + & - & - & + & + \\
\hline L-Rhamnose & - & + & + & + & + & - & - & + & + \\
\hline Sucrose & + & - & + & + & + & + & - & + & + \\
\hline D-Xylose & + & + & + & + & + & + & ND & + & + \\
\hline \multicolumn{10}{|l|}{ Utilization of: } \\
\hline L-Arabinose & - & + & + & + & + & + & - & - & - \\
\hline D-Glucose & + & + & + & + & + & + & - & + & + \\
\hline D-Mannose & + & + & + & + & + & + & - & + & + \\
\hline Malate & - & $\mathrm{V}$ & - & - & - & - & - & - & - \\
\hline \multicolumn{10}{|l|}{ Susceptibility to: } \\
\hline Carbenicillin & - & + & + & - & $\mathrm{V}$ & + & ND & + & - \\
\hline Lincomycin & - & + & + & + & $\mathrm{V}$ & + & ND & + & + \\
\hline Oleandomycin & - & + & + & - & + & + & ND & + & + \\
\hline Tetracycline & - & + & + & - & $\mathrm{V}$ & + & $\mathrm{ND}$ & - & - \\
\hline DNA G $+\mathrm{C}$ content $(\mathrm{mol} \%)$ & $49 \cdot 0$ & $35-37$ & 41 & $37-40$ & $39-42$ & 37 & $40-41$ & 41 & 42 \\
\hline
\end{tabular}


$(250 \times 4 \cdot 6 \mathrm{~mm})$ column. For fatty acid methyl ester analysis, cell mass of strain DS- $44^{\mathrm{T}}$ was harvested from MA plates after incubation for 7 days at $25^{\circ} \mathrm{C}$. The fatty acid methyl esters were extracted and prepared according to the standard protocol of the MIDI/Hewlett Packard Microbial Identification System (Sasser, 1990). The DNA G + C content was determined by the method of Tamaoka \& Komagata (1984) with the modification that DNA was hydrolysed and the resultant nucleotides were analysed by reversed-phase HPLC.

The morphological, cultural, physiological and biochemical characteristics of strain DS- $44^{\mathrm{T}}$ are given in the species description (see below) or are shown in Table 1. The almostcomplete $16 \mathrm{~S}$ rRNA gene sequence of strain DS- $44^{\mathrm{T}}$, comprising $1479 \mathrm{nt}$ (approx. $96 \%$ of the Escherichia coli 16S rRNA gene sequence), was determined in this study. 16S rRNA gene sequence analyses showed that strain DS- $44^{\mathrm{T}}$ was most closely affiliated to the genus Algoriphagus of the phylum Bacteroidetes (Fig. 1). In the neighbour-joining tree based on 16S rRNA gene sequences, strain DS- $44^{\mathrm{T}}$ fell within the radiation of the cluster comprising Algoriphagus species (Fig. 1). The same tree topology was found in the trees generated with the maximum-likelihood and maximumparsimony algorithms (Fig. 1). Strain DS- $44^{\mathrm{T}}$ exhibited $16 \mathrm{~S}$ rRNA gene sequence similarity values of $93 \cdot 8-95 \cdot 7 \%$ with respect to the eight recognized Algoriphagus species, 93.2$93 \cdot 4 \%$ with respect to Hongiella species and less than $89 \cdot 8 \%$ with respect to the other species used in the phylogenetic analysis.

Strain DS- $44^{\mathrm{T}}$ contained MK-7, at a peak area ratio of approximately $97 \%$, as the predominant isoprenoid quinone. The fatty acid profile of strain DS- $44^{\mathrm{T}}$ comprised $(>1.0 \%$ of total fatty acids) branched fatty acids iso$\mathrm{C}_{15: 0}(35 \cdot 3 \%)$, iso- $\mathrm{C}_{17: 1} \omega 9 c(8 \cdot 5 \%)$, iso- $\mathrm{C}_{16: 1} \mathrm{H}(2 \cdot 5 \%)$, anteiso- $\mathrm{C}_{15: 0}(2 \cdot 4 \%)$, anteiso- $\mathrm{C}_{11: 0}(1 \cdot 6 \%)$, iso- $\mathrm{C}_{11: 0}$ $(1 \cdot 1 \%)$, iso- $\mathrm{C}_{14: 0}(1 \cdot 0 \%)$, iso- $\mathrm{C}_{15: 1} \mathrm{G}(1 \cdot 0 \%)$ and iso$\mathrm{C}_{16: 0}(1 \cdot 0 \%)$, summed feature 3 , comprising $\mathrm{C}_{16: 1} \omega 7 \mathrm{c}$ and/ or iso- $\mathrm{C}_{15: 0} 2-\mathrm{OH}(24 \cdot 5 \%)$, and summed feature 4 , comprising iso- $\mathrm{C}_{17: 1} \mathrm{I}$ and/or anteiso- $\mathrm{C}_{17: 1} \mathrm{~B}(2 \cdot 5 \%)$, hydroxy fatty acids iso- $\mathrm{C}_{17: 0} 3-\mathrm{OH}(6.9 \%)$ and iso- $\mathrm{C}_{15: 0} 3-\mathrm{OH}$ $(3 \cdot 2 \%)$ and unsaturated fatty acids $\mathrm{C}_{16: 1} \omega 5 c(2 \cdot 8 \%)$ and $\mathrm{C}_{15: 1} \omega 6 c(1 \cdot 0 \%)$. This fatty acid profile was similar with those of previously analysed Algoriphagus species, although there were differences in the proportions of some fatty acids, perhaps because of differences in cultivation conditions (see Supplementary Table S1 in IJSEM Online). The DNA G + C content of strain DS- $44^{\mathrm{T}}$ was $49 \cdot 0 \mathrm{~mol} \%$, which is higher than those of other Algoriphagus species (Table 1). These chemotaxonomic properties were in agreement with the result of monothetic phylogenetic classification of strain DS- $44^{\mathrm{T}}$ as a member of the genus Algoriphagus (Bowman et al., 2003; Nedashkovskaya et al., 2004; Van Trappen et al., 2004; Yoon et al., 2005a, b). Strain DS- $44^{\mathrm{T}}$ was distinguishable from other Algoriphagus species by means of differences in several phenotypic properties, as shown in Table 1 . The $16 \mathrm{~S}$ rRNA gene sequence similarity data were sufficient to allocate strain DS $-44^{\mathrm{T}}$ to a species that is separate from the recognized Algoriphagus species (Stackebrandt \& Goebel, 1994). Therefore, on the basis of the data presented, strain DS- $44^{\mathrm{T}}$ should be placed in the genus Algoriphagus as a member of a novel species, for which the name Algoriphagus terrigena sp. nov. is proposed.

\section{Description of Algoriphagus terrigena sp. nov.}

Algoriphagus terrigena (ter.ri.ge'na. L. masc. or fem. n. terrigena child of the earth, referring to the isolation of the type strain from soil).

Cells are Gram-negative, non-spore-forming, non-flagellated short rods or rods $(0 \cdot 4-0 \cdot 6 \times 0 \cdot 8-2 \cdot 5 \mu \mathrm{m})$; a few cells greater than $50 \mu \mathrm{m}$ in length are also observed. Colonies on MA are circular, convex, smooth, glistening, light orange in colour and $1 \cdot 0-2 \cdot 0 \mathrm{~mm}$ in diameter after incubation for 7 days at $25^{\circ} \mathrm{C}$. Optimal growth occurs at $25^{\circ} \mathrm{C}$; growth occurs at 10 and $36^{\circ} \mathrm{C}$, but not at 4 or $37^{\circ} \mathrm{C}$. Optimal pH for growth is $6 \cdot 5-7 \cdot 5$; growth occurs at $\mathrm{pH} 5 \cdot 5$, but not at $\mathrm{pH} 5 \cdot 0$. Optimal growth occurs in the presence of $2 \%(\mathrm{w} / \mathrm{v}) \mathrm{NaCl}$; growth does not occur in the absence of $\mathrm{NaCl}$ or in the presence of $>7 \%(\mathrm{w} / \mathrm{v}) \mathrm{NaCl}$. Growth does not occur under anaerobic conditions on MA or on MA supplemented with nitrate. Aesculin and Tweens 20, 40 and 60 are hydrolysed, but hypoxanthine, xanthine, L-tyrosine and urea are not. $\mathrm{H}_{2} \mathrm{~S}$ is not produced. Arginine dihydrolase, lysine decarboxylase, ornithine decarboxylase and tryptophan deaminase are absent. In assays with the API ZYM system, alkaline

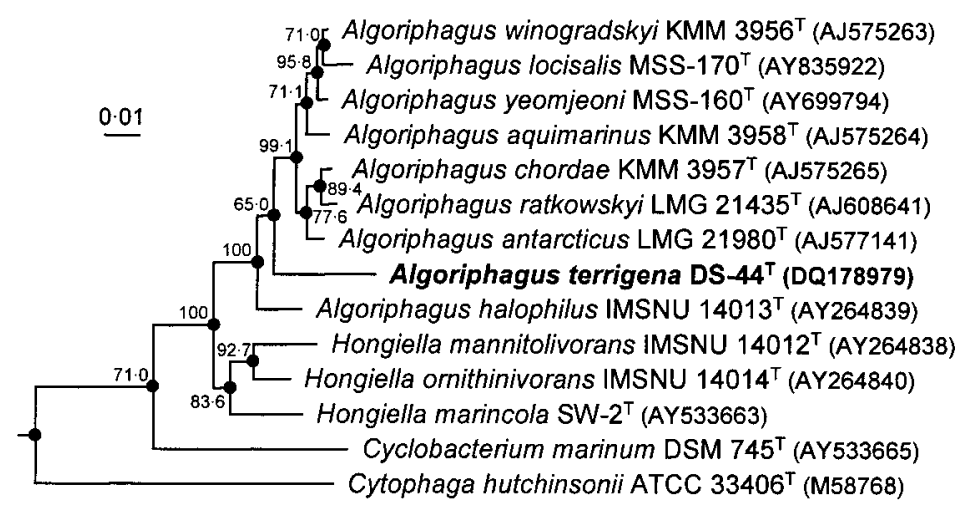

Fig. 1. Neighbour-joining phylogenetic tree, based on 16S rRNA gene sequences, showing the positions of strain DS $-44^{\top}$ and some other related taxa. Numbers at nodes are bootstrap values (1000 replications), given as percentages; only values greater than $50 \%$ are shown. Flavobacterium aquatile IAM $12316^{\top}$ was used as outgroup. Dots indicate that the corresponding nodes were also recovered in the trees generated with the maximum-likelihood and maximumparsimony algorithms. Bar, 0.01 substitutions per nucleotide position. 
phosphatase, esterase (C4), esterase lipase (C8), leucine arylamidase, valine arylamidase, trypsin, $\alpha$-chymotrypsin, acid phosphatase, naphthol-AS-BI-phosphohydrolase, $\beta$-galactosidase, $\alpha$-glucosidase, $\beta$-glucosidase and $N$-acetyl$\beta$-glucosaminidase are present, $\alpha$-mannosidase is weakly present, but lipase (C14), cystine arylamidase, $\alpha$-galactosidase, $\beta$-glucuronidase and $\alpha$-fucosidase are absent. D-Cellobiose, D-fructose, D-galactose, maltose, sucrose, D-trehalose, D-xylose and salicin are utilized as sole carbon and energy sources, but acetate, benzoate, formate, L-glutamate, pyruvate and succinate are not utilized. Acid is produced from D-mannose, D-raffinose and D-trehalose, weakly produced from D-fructose, D-melezitose and D-ribose, but not produced from myo-inositol, D-mannitol or D-sorbitol. Susceptible to chloramphenicol and novobiocin, but not to cephalothin. The predominant menaquinone is MK-7. The major fatty acids ( $>10 \%$ of total fatty acids) are iso- $\mathrm{C}_{15: 0}$ and $\mathrm{C}_{16: 1} \omega 7 c$ and/or iso- $\mathrm{C}_{15: 0}$ 2-OH. The DNA G+C content is $49 \cdot 0 \mathrm{~mol} \%$ (HPLC). Other phenotypic properties are shown in Table 1.

The type strain, DS $-44^{\mathrm{T}}\left(=\right.$ KCTC $12545^{\mathrm{T}}=$ CIP $\left.108837^{\mathrm{T}}\right)$, was isolated from soil from Dokdo, Korea.

\section{Acknowledgements}

This work was supported by the 21C Frontier Program of Microbial Genomics and Applications (grant MG05-0401-2-0) from the Ministry of Science and Technology (MOST) of the Republic of Korea. We are grateful to Ulleung County Administration and the Cultural Heritage Administration of the Republic of Korea for facilitating access to Dokdo.

\section{References}

Baumann, P. \& Baumann, L. (1981). The marine Gram-negative eubacteria: genera Photobacterium, Beneckea, Alteromonas, Pseudomonas, and Alcaligenes. In The Prokaryotes, pp. 1302-1331. Edited by M. P. Starr, H. Stolp, H. G. Trüper, A. Balows \& H. G. Schlegel. Berlin: Springer.

Bowman, J. P. (2000). Description of Cellulophaga algicola sp. nov., isolated from the surfaces of Antarctic algae, and reclassification of Cytophaga uliginosa (ZoBell and Upham 1944) Reichenbach 1989 as Cellulophaga uliginosa comb. nov. Int J Syst Evol Microbiol 50, 1861-1868.

Bowman, J. P., Nichols, C. M. \& Gibson, J. A. E. (2003). Algoriphagus ratkowskyi gen. nov., sp. nov., Brumimicrobium glaciale gen. nov., sp. nov., Cryomorpha ignava gen. nov., sp. nov. and Crocinitomix catalasitica gen. nov., sp. nov., novel flavobacteria isolated from various polar habitats. Int J Syst Evol Microbiol 53, 1343-1355.

Bruns, A., Rohde, M. \& Berthe-Corti, L. (2001). Muricauda ruestringensis gen. nov., sp. nov., a facultatively anaerobic, appendaged bacterium from German North Sea intertidal sediment. Int J Syst Evol Microbiol 51, 1997-2006.

Cohen-Bazire, G., Sistrom, W. R. \& Stanier, R. Y. (1957). Kinetic studies of pigment synthesis by nonsulfur purple bacteria. J Cell Comp Physiol 49, 25-68.
Cowan, S. T. \& Steel, K. J. (1965). Manual for the Identification of Medical Bacteria. London: Cambridge University Press.

Komagata, K. \& Suzuki, K. (1987). Lipid and cell wall analysis in bacterial systematics. Methods Microbiol 19, 161-207.

Lanyi, B. (1987). Classical and rapid identification methods for medically important bacteria. Methods Microbiol 19, 1-67.

Leifson, E. (1963). Determination of carbohydrate metabolism of marine bacteria. J Bacteriol 85, 1183-1184.

Nedashkovskaya, O. I., Vancanneyt, M., Van Trappen, S. \& 7 other authors (2004). Description of Algoriphagus aquimarinus sp. nov., Algoriphagus chordae sp. nov. and Algoriphagus winogradskyi sp. nov., from sea water and algae, transfer of Hongiella halophila Yi and Chun 2004 to the genus Algoriphagus as Algoriphagus halophilus comb. nov. and emended description of the genera Algoriphagus Bowman et al. 2003 and Hongiella Yi and Chun 2004. Int J Syst Evol Microbiol 54, 1757-1764.

Reichenbach, H. (1992). The order Cytophagales. In The Prokaryotes. A Handbook on the Biology of Bacteria: Ecophysiology, Isolation, Identification, Applications, 2nd edn, pp. 3631-3675. Edited by A. Balows, H. G. Trüper, M. Dworkin, W. Harder \& K. H. Schleifer. New York: Springer.

Sasser, M. (1990). Identification of bacteria by gas chromatography of cellular fatty acids. Technical Note 101. Newark, DE: MIDI.

Stackebrandt, E. \& Goebel, B. M. (1994). Taxonomic note: a place for DNA-DNA reassociation and $16 \mathrm{~S}$ rRNA sequence analysis in the present species definition in bacteriology. Int J Syst Bacteriol 44, 846-849.

Staley, J. T. (1968). Prosthecomicrobium and Ancalomicrobium: new prosthecate freshwater bacteria. J Bacteriol 95, 1921-1942.

Tamaoka, J. \& Komagata, K. (1984). Determination of DNA base composition by reverse-phase high-performance liquid chromatography. FEMS Microbiol Lett 25, 125-128.

Van Trappen, S., Vandecandelaere, I., Mergaert, J. \& Swings, J. (2004). Algoriphagus antarcticus sp. nov., a novel psychrophile from microbial mats in Antarctic lakes. Int J Syst Evol Microbiol 54, 1969-1973.

Yi, H. \& Chun, J. (2004). Hongiella mannitolivorans gen. nov., sp. nov., Hongiella halophila sp. nov. and Hongiella ornithinivorans sp. nov., isolated from tidal flat sediment. Int J Syst Evol Microbiol 54, 157-162.

Yoon, J.-H., Km, H., Kim, S.-B., Kim, H.-J., Kim, W. Y., Lee, S. T., Goodfellow, M. \& Park, Y.-H. (1996). Identification of Saccharomonospora strains by the use of genomic DNA fragments and rRNA gene probes. Int J Syst Bacteriol 46, 502-505.

Yoon, J.-H., Lee, S. T. \& Park, Y.-H. (1998). Inter- and intraspecific phylogenetic analysis of the genus Nocardioides and related taxa based on 16S rRNA gene sequences. Int J Syst Bacteriol 48, 187-194.

Yoon, J.-H., Kim, I.-G., Shin, D.-Y., Kang, K. H. \& Park, Y.-H. (2003). Microbulbifer salipaludis sp. nov., a moderate halophile isolated from a Korean salt marsh. Int J Syst Evol Microbiol 53, 53-57.

Yoon, J.-H., Kang, S.-J., Jung, S.-Y., Lee, C.-H. \& Oh, T.-K. (2005a). Algoriphagus yeomjeoni sp. nov., isolated from a marine solar saltern of the Yellow Sea, Korea. Int J Syst Evol Microbiol 55, 865-870.

Yoon, J.-H., Kang, S.-J. \& Oh, T.-K. (2005b). Algoriphagus locisalis sp. nov., isolated from a marine solar saltern. Int J Syst Evol Microbiol 55, 1635-1639. 